China Perspectives

$2011 / 3$ | 2011

Chinese Medicine: The Global Influence of an Evolving Heritage

\title{
Chinese Medicine in Cameroon
}

\section{Hilaire De Prince Pokam}

Translator. Jonathan Hall

\section{OpenEdition}

\section{Journals}

Electronic version

URL: http://journals.openedition.org/chinaperspectives/5642

DOI: 10.4000/chinaperspectives.5642

ISSN: 1996-4617

\section{Publisher}

Centre d'étude français sur la Chine contemporaine

\section{Printed version}

Date of publication: 1 October 2011

Number of pages: $51-58$

ISSN: 2070-3449

Electronic reference

Hilaire De Prince Pokam, « Chinese Medicine in Cameroon », China Perspectives [Online], 2011/3 | 2011, Online since 25 September 2014, connection on 28 October 2019. URL : http://

journals.openedition.org/chinaperspectives/5642 ; DOI : 10.4000/chinaperspectives.5642

(C) All rights reserved 


\title{
Chinese Medicine in Cameroon
}

\author{
HILAIRE DE PRINCE POKAM*
}

\begin{abstract}
China's arrival on the African economic scene is overturning the balance of forces in place since the independence of African countries. Africa is regarded by some as a "new hunting ground" or "promised land" for China, making it part of its global strategy. This article sets out to examine one of China's so-called "soft power" strategies, represented by the widespread practice of Traditional Chinese Medicine (hereafter TCM) overseas. It focuses on Cameroon, which is a mainstay for Central Africa on account of its harbour and its regional economic dominance.
\end{abstract}

KEYWORDS: Cameroon, China, Traditional Chinese Medicine, migration, transnationalism.

A s Africa's third leading trading partner, as a strategic investor participating in its development, and as its increasingly important source of finance, the People's Republic of China (PRC) is overturning the balance of power in place since the countries of the continent became independent. This has reached the point where the "traditional partners," Europe, the United States, and France in particular, are raising questions about their relations with Africa. The African continent is considered by some to be China's "new hunting ground" (1) or its "promised land" (2) within its overall strategic objectives. ${ }^{(3)}$ François Lafargue even describes China as an African power. ${ }^{(4)}$ To achieve these objectives, China makes use of a range of seductive strategies, (5) including the strategic use of "soft power," (6) which means that the leadership has opted for pragmatism and patience in its competition with the other leading powers. ${ }^{(7)}$ Traditional Chinese medicine (TCM) is part of this strategy.

Cameroon and China established diplomatic relations in 1971. The mutual trust between the two countries then led to the signing of many bilateral agreements ${ }^{(8)}$ and encouraged the immigration of Chinese people. In order to expand the range of its partnerships, and thereby reduce the indigence of its own people, China's enterprises and government have turned their attention to the developing countries of the South. For these countries, China is a favoured trading partner, and the major economic reforms in China, together with opportunities provided by Cameroon, have given a new boost to Chinese immigration into that country. Over his 29 years in power, the current President of Cameroon has made five visits to China, and Chinese leaders have also visited Cameroon, thus consolidating relations between the two countries.

In light of the importance that China attaches to Cameroon, a study of the practice of TCM in that country appears pertinent for a greater understanding of one aspect of China's power strategies in Africa. Such a study should enable the appreciation of an activity rarely considered transnational even though it is conducted by some of the Chinese population in Cameroon, and to show by this concrete example how Chinese medicine also forms one of the links in the building of transnational networks by overseas Chinese. This analysis therefore adopts a deliberately transnational perspective in considering the way private individuals play a role in global politics. (9) This applies specifically to Chinese doctors working in Cameroon, who by their very presence consolidate the influence of transnational relations. ${ }^{(10)}$
Based on a sociological approach that takes account of responses by doctors and patients to a series of questions, my hypothesis is as follows: the Chinese population in Cameroon forms part of a triangular social structure that links them to their native country and to the host nation, (11) and is activated by the practice of TCM among other things. While this medical activity may be beneficial for Cameroon, despite its problematic nature in some respects, it is certainly a power strategy for China, which participates in its diffusion. This is reinforced by the situation within the two societies, for "it is the developments taking place within this overall structure that provide the main explanations for the phenomena of international and transnational solidarity." (12)

Hilaire de Prince Pokam holds a doctorate in political science from the University of Paris X-Nanterre. He teaches at Dschang University (Cameroon), and is a member of the International Political Sciences Association, the Swiss Association of Political Science, the Asia Research Group, and the Council for the Development of Social Sciences Research in Africa. His current research is concerned with the relations between the developed countries and the emergent countries in Africa, the international community and African governments, as well as the committees supervising elections in sub-Saharan Africa.

1. Julien Nessi, "L'Afrique, nouveau terrain de chasse de la China," www.newropeans-magazine.org/content/view/5408/43/lang,english (consulted on 31 October 2011).

2. Jiang Chung-lian, "La Chine et le pétrole et l'Afrique" (28/11/2004): www.geopolitis.net/GEO ENERGIE/CHINE PETROLE AFRIQUE.pdf (consulted on 31 October 2011).

3. For some of the data supporting this view, see Marie Bal and Laura Valentin, La stratégie de puissance de la Chine en Afrique, ESSEC, June 2008, p. 6.

4. François Lafargue, "China's Presence in Africa," China Perspectives, no. 61, 2005, pp. 2-9.

5. According to Christophe Stalla-Bourdillon, "The seductive approach is China's way of penetrating Africa," quoted by Marie Bal and Laura Valentin, op. cit., pp. 54 and 60.

6. This term was first used in Britain in the nineteenth century, and was first applied to international relations by Robert Nye, an American scholar in the field. It refers to the capacity of an organisation to influence the behaviour of its target in pursuit of its interests by non-coercive means. For further details see Joseph Nye, The Power to Lead, New York, Oxford University Press, 2008

7. In January 2006, Chairman Hu Jintao stated that "increasing China's international status and influence must be reflected in our use of hard power, including the economy, science, and technology, as well as our soft power, such as culture." Guy Gweth, "La stratégie de puissance chinoise en Afrique vue du Cameroun," http://diplogeostrategies.blogspot.com/2011/01/la-strategie-de-puissance-chinoiseen.html (consulted on 31 October 2011).

8. These bilateral agreements cover several areas, including social aid for the improvement of health care.

9. For further details on transnational theory, see Dario Batistella, Théorie des relations internationales, Paris, FNSP press, 2003, pp. 175-204; Rainer Bauböck and Thomas Faist (eds.), Diaspora and transnationalism: Concepts, theories and methods, Amsterdam, Amsterdam University Press, 2010.

10. For more precise details on the concept of transnational relations, see Dario Batistella, op. cit., pp. 181182.

11. In this regard Safran writes, "Diasporas exist in a triangular socio-cultural relationship with both the host country and the motherland" (Rainer Bauböck and Thomas Faist, op. cit., p. 20).

12. Guillaume Devin, "Les solidarités transnationales, phénomène social à l'échelle mondiale," in Guillaume Devin (ed.), Les solidarités transnationales, Paris, L'Harmattan, 2004, p. 15. 


\section{Figure 1 - Map of Cameroon}

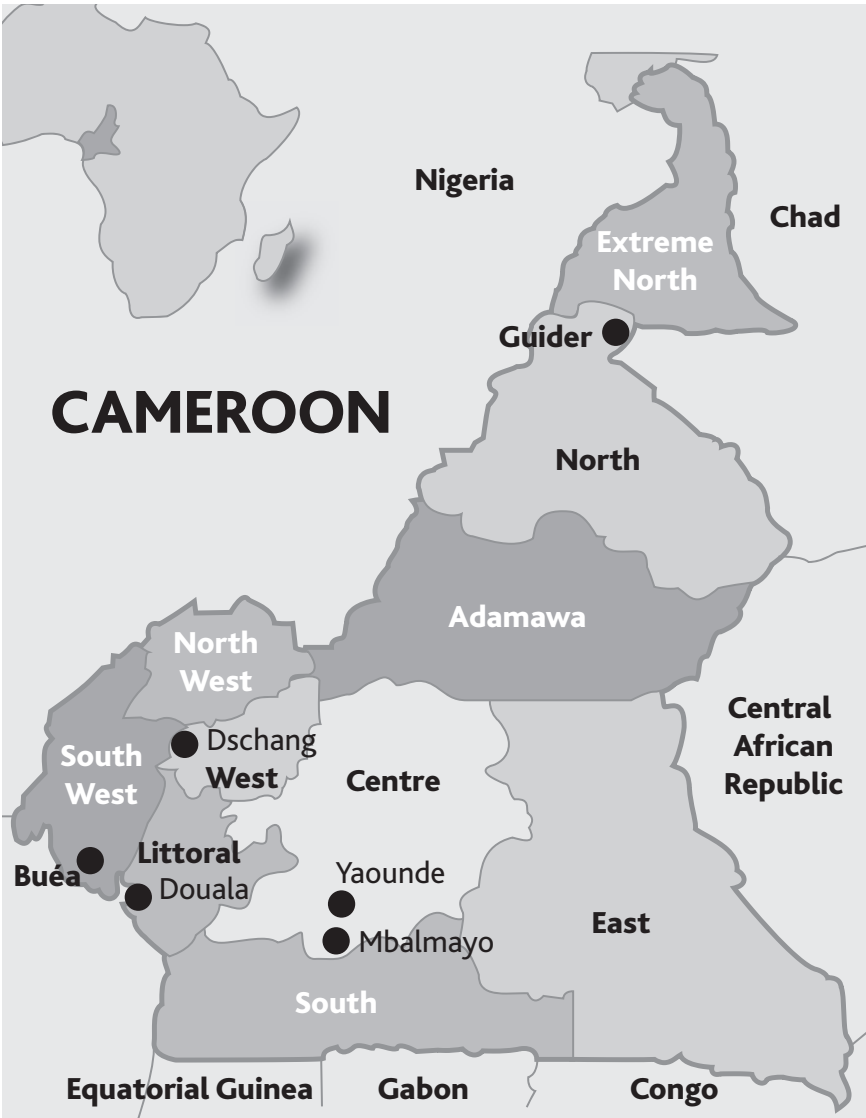

\section{Strategies for the diffusion of TCM in Cameroon}

The presence of TCM in Cameroon is above all the outcome of strategies on the part of the Chinese government, and these strategies greatly influence its reception. This activity is part of China's policy of encouraging the spread of TCM worldwide, and it requires support through investments and the circulation of personnel. Cameroon's response shows that, like most African countries, it has adopted what Giles Mohan calls a "laissez-faire response" to Chinese aid and investment. ${ }^{(13)}$

Ever since the founding of the PRC in 1949, the Chinese government has supported TCM by integrating it into its public health system along lines similar to its support for biologically based medicine. (14) The process that imposed government support, along with the standardisation of medical practices, has led to the current situation in which TCM is used in the large university hospitals alongside the latest developments in Western medicine. The WHO also supports the diffusion of TCM.

The export of TCM to Africa largely takes place within the arrangements agreed for bilateral co-operative programmes. Whereas these programmes began in the Maoist era as forms of joint co-operation, nowadays they more closely resemble private entrepreneurial ventures. Under Mao, the earlier arrivals to Africa worked within co-operative arrangements, but now Chinese doctors coming to the continent are above all businessmen. They are private entrepreneurs who set up their businesses at their own expense, seeking economic success and personal reputation through the provision of TCM services.

\section{Chinese medical investments in Cameroon}

Investments make up a particularly visible sector of the co-operation between China and Cameroon, covering both infrastructure and medical supplies. Immediately after the establishment of diplomatic relations with Cameroon, China built hospitals at Guider and Mbalmayo, which are among the largest in the country. The Chinese contributed to the development of low-cost basic health services, and the agreement was to provide for a combination of Western and traditional Chinese medicine.

The Yaoundé Hospital of Gynaecological Obstetrics and Paediatrics is the most recent major health project completed under the provisions of the Sino-Cameroonian agreements. It was built in Ngousso and opened by the Head of State in 2002, in the presence of the Chinese ambassador and China's vice-Minister of Health, Ma Xiaowei. It is now one of the largest in the country, having cost 5 billion FCFA (7.6 million euros). (15) Its entry into service has strengthened medical co-operation between Cameroun and China. It provides two kinds of care: Western medicine and TCM. Also, the Buéa regional hospital has been completely refitted at a cost of 3 billion FCFA (4.5 million euros) thanks to this co-operation.

Since October 2009, another hospital for gynaecological obstetrics and paediatrics has been under construction in Yassa, on the outskirts of Douala. In a few months it will be the second modern hospital complex built for Cameroun under the terms of the co-operation with China. This investment will lead to the construction of 11 buildings and the provision of 300 beds, which is 100 more than in Yaoundé. Like the latter, it will be able to offer up-to-date services in medical imaging, obstetric gynaecology, ear and throat treatment, stomatology, paediatrics, and TCM. The overall cost will be 9.9 billion FCFA (15 million euros), of which China's share will amount to 3.7 billion FCFA (5.6 million euros). The Chinese government supplies the medicines and medical apparatus for these hospitals, which it planned and oversaw during construction.

As for further items of equipment, in 2004 the Guider hospital received a generator to produce electricity in the event of a power cut by the national electricity company. This reduces the risks arising from power cuts during surgical operations. In 2005 there was a similar gift of equipment valued at 91 million FCFA (140,000 euros). ${ }^{(16)}$ The availability of this equipment helps make this hospital one of the most complete and best furnished in Cameroun. And since the Mbalmayo and Yaoundé hospitals were set up, they have also benefited from further investments resulting in a great deal of additional equipment provided by the PRC. To all this should be added large quantities of TCM products.

\section{The circulation of personnel favoured by these projects}

In the modern world, the patterns of Chinese migration continue a centuries-old process that expanded rapidly in the mid-nineteenth century.

13. Giles Mohan and May Tan-Mullins, "Chinese migrants in Africa as new agents of development? An analytical framework," European Journal of Development Research, vol. 21, no. 4, 2009, pp. 588-605.

14. Evelyne Micollier, "Les transformations de la médecine chinoise en Chine: recherche et développement, circulation des savoirs et des pratiques," a paper presented at the 3rd Congress of the Réseau AsieIMASIE, 26-28 September 2007, Paris, p. 3.

15. François Wassoumi, "La présence chinoise au Cameroun et son influence sur les pratiques de santé," Revue de sociologie, d'anthropologie et de psychologie, no. 2, Sheik Anta Diop University, Faculty of Arts and Human Sciences, 2010, p. 101.

16. This included a multi-purpose $x$-ray machine, two electrocardiographs, one sonar imaging machine, four cardioscopes, one multi-functional anaesthetic machine, one ophthalmoscope, one electric bed, one dental chair, two computers, one pressurised disinfector, one surgical microscope, two infrared lamps, two life-support machines, and one digital photocopier. 
Within this extended history, the opening-up of China and the liberalisation of the conditions for emigration in 1985 led to a return to these patterns. Between 1982 and 2000, annual Chinese migration rose from 56,930 to 756,626, according to Beijing's own statistics. ${ }^{(17)}$ Apart from Southeast Asia, the other destinations are mostly in the West, in the broad sense of the word: i.e., North America, Western Europe, Australia, and New Zealand.

As for Chinese migration to Africa, that has existed for at least 500 years, but it has rapidly taken off in the last five years in particular. ${ }^{(18)}$ There have been three phases to Chinese immigration into Africa. Although there had already been contacts between China and Africa across the Indian Ocean, it was only from the mid-nineteenth century onwards that systematic migration really began. It lasted from 1850 to 1950 and was aimed mainly at providing labour for colonial projects. Between 1960 and 1980, following the founding of the PRC and onset of the Cold War, relations between China and Africa entered a more political phase. Chinese aid then served to strengthen solidarity between southern nations in several areas, such as agriculture and medicine. ${ }^{(19)}$ From 1990 to the present, there has been an increase in migration resulting from the Chinese economic reforms initiated in the late 1970s, and it has become even more pronounced over the last five years. As Emmanuel Ma Mung notes, Africa has seen an increase in Chinese immigration since the late 1990s. He makes a distinction between three kinds of migration from China: temporary labour migration, proletarian migration in transit, and migration for business. ${ }^{(20)}$ To this we should add the new wave of migration since the opening of China's frontiers in the 1980s. This consists partly of students, traders, and doctors, who provide support for the political influence of the Chinese government. The latter's encouragement of this form of migration can be clearly seen through its support for the Chinese medical personnel in Cameroon who belong to this wave of "new migrants." (21)

The Chinese government encourages its doctors to emigrate by negotiating the terms of their freedom of movement in the agreement it signs with Cameroon in the field of health care co-operation. It then makes arrangements for their stay. In 2006, for example, 44 new Chinese doctors arrived to take over from the team that had been there for two years. Two agreements covering their reception were signed between China and Cameroon. The first of these contained a contract to carry out the building of housing for the Yaoundé team, amounting to 650 million FCFA $(992,000$ euros).

Since 1975, structural arrangements by the Chinese government in the health sector have given rise to the immigration of numerous Chinese doctors on a temporary basis. On 9 June 1975, a protocol was signed to cover the despatch of medical teams by China. This document stipulates that every Chinese team has a two-year mandate. Their task is to set up close co-operation with Cameroonian medical personnel in order to provide support in remedial medicine, to work in conjunction with their medical and paramedical counterparts, to share work experience, to teach medical techniques, and to encourage the further training of Cameroonians back in China. (22) This protocol is signed every time the teams are renewed, so it has undergone several revisions since 1975. Between 1980 and 1985, cooperation was suspended and so were the periods of stay by the Chinese teams. It was resumed in 1985 with the signing of a new agreement.

The Cameroonian Ministry of Health chooses where the teams operate. The towns of Mbalmayo, Guider, and Yaoundé were selected. The basis of the co-operation having been decided, the first teams reached Mbalmayo in 1975 and Guider in late 1976.
Chinese teams usually consist of about ten people per workplace. The first one, which came to Guider in 1976, had 14 members and consisted largely of specialists in a wide range of fields, ${ }^{(23)}$ whereas Cameroonian doctors are mostly general practitioners. Since this co-operation was set up, all the teams that have succeeded each other in the three localities have had the same make-up, with a few exceptions. Between 1975 and 2011, there have been 15 Chinese missions working in Cameroon, amounting to roughly 700 doctors.

All these doctors work as expatriates for the two years laid down in the agreements and go home when their contracts expire. Those who wish to stay for four years have to argue vociferously to have their contracts extended. (24) Such is the case of Professor Tang, the head of the current mission. He is on his second round, having completed his first in Guider between 1978 and 1981. In general, these doctors come and go as a single group. (25) Up until now, none of them has returned to settle privately in Cameroon as have some of the Chinese medical practitioners in Tanzania mentioned by Elisabeth Hsu. (26)

In these hospitals, the Chinese care personnel work together with their Cameroonian counterparts, to whom they impart their knowledge of TCM despite the language barriers. At the Ngousso hospital, (27) for example, Cameroonian and Chinese specialists work harmoniously together. This medical centre is known for the excellence of its staff. On their admission, patients can be treated by either a Cameroonian or a Chinese doctor.

Chinese doctors seem to have little contact with the local population, and live in a closed world made all the more so because they live in camps built to house them under the terms of the agreements. Such obstacles to closer integration also arise from the language problem: "They have a smattering of French and can get by a little better in English, but they do try to learn some elements of the local language because they have some translation booklets." (28) Even at the culinary level, adaptation is far from certain: "They come with their own cooks, and eat very little of our food. They eat Chinese dishes, preferring only our beer." (29)

17. Laurence Roulleau-Berger, "Nouvelles migrations chinoises et marchés de travail," in Laurence Roulleau-Berger (ed.), Nouvelles migrations chinoises et travail en Europe, Toulouse, Presses universitaires du Mirail, 2007, p. 33

18. Giles Mohan and Dinar Kale, "The invisible hand of South-South globalisation: Chinese migrants in Africa," A Report for the Rockefeller Foundation prepared by The Development Policy and Practice Deparment, The Open University, Milton Keynes, October 2007, p. 2.

19. Ibid., p. 9.

20. Emmanuel Ma Mung, "Chinese migrations and China's policy in Africa," Journal of Chinese Overseas, vol. 4, no. 1, pp. 91-109.

21. This term refers to "those Chinese citizens who have been emigrating elsewhere since 1979, when China started on its economic reforms." Liu Hong, "New migrants and the revival of Overseas Chinese Nationalism," Journal of Contemporary China, vol. 14, no. 43, May 2005, p. 293.

22. Non-classified documents of the Ministry of Health, "Protocole d'accord entre la République unie du Cameroun et la République populaire de Chine relatif à l'envoi par la Chine d'une équipe médicale au Cameroun," 1975.

23. These included two surgeons (one orthopaedic and one general), one opthamologist, a radiologist, a nose-and-throat specialist, an acupuncturist, an obstetric gynaecologist, an anaesthetist, a cook, an interpreter, and a driver (François Wassouni,"La présence chinoise au Cameroun et son influence sur les pratiques de santé," art. cit., p. 100).

24. According to an interview with a nurse at the Yaoundé hospital on 11 July 2011.

25. Ibid.

26. Elisabeth Hsu, "Medicine as business: Chinese medicine in Tanzania," art. cit:; "Zanzibar and its Chinese Communities," art. cit.

27. It has been very difficult to get precise information from Chinese doctors, who seem mistrustful, which is why, for the purposes of this study, I have had to rely on conversations conducted through a nurse working in the Ngousso hospital, rather than through questionnaires.

28. Interview with the nurse mentioned above.

29. Ibid. 
It seems that, as has been observed elsewhere, "de-territorialisation" goes together with, or is followed by, a movement of "re-territorialisation." That is to say, despite the change of place, the Chinese community seeks "to preserve its identity and to reproduce it in spite of the distance from home," (30) laying the basis for what Emmanuel Ma Mung calls a "transnational ethnic identity." (31)

Under the terms of the 1975 agreement, the PRC also undertakes to provide specialist training to a large number of Cameroonian doctors. This favours the transmission of China's traditional medicine, which is confirmed by the testimony of two Cameroonian doctors who were the first to benefit from China's training programmes in TCM, even though at the time this was not explicitly laid out in the wording of the agreement. These two Cameroonian doctors were awarded a WHO grant at a time when acupuncture was becoming fashionable, and they went to China in 1977 for three months' training at the TCM Institute in Shanghai. ${ }^{(32)}$ In fact, China has awarded around ten grants per year to support the medical training of Cameroonian students. ${ }^{(33)}$

A large-scale medical training programme has also been established within the Cameroonian university system, with the participation of Chinese teachers and researchers. In 1991, the joint microbiological research project between the universities of Zhejiang and Yaoundé was launched. In 2003 Cameroon signed an agreement for a joint project on training, research, and assessment of Cameroonian and Chinese medicinal plants and traditional medicines. On the Cameroonian side, its operations are conducted by the University of Yaounde 1 and the Institute for medicinal research and medicinal plant studies (IMPM), and on the Chinese side by the University of Zhejiang.

\section{The economic stakes in the medicine market}

The Chinese government also participates in the distribution of medicines in Cameroon. On the one hand, this takes place through the dispensaries of the hospitals in Yaoundé, Mbalmayo, and Guider, which sell TCM products to the patients of Chinese doctors in accordance with the 1975 agreement, and on the other hand, through the Chinese Pharmaceutical Cameroon company. With the agreement of the Ministry of Public Health, this company has penetrated the Cameroonian public health sector. It has exclusive rights over the sale of a medicine for treating malaria manufactured by Guilin Southern Pharmaceuticals, a laboratory based in the Chinese city of Guilin. Since 2004, this medicine has been recommended by the WHO. It is a single treatment in two separate forms: as an injection, it is called Artesunate, and in tablet form it is called Arsuamoon. The latter can be used for the treatment of every type of malaria, whereas Artesunate is used for cases affecting the nervous system, and also for emergency cases when, for example, the patient is in a coma. To combat the disease effectively, the WHO suggests a combination of Artesunate and Amodiaquine. These medicines are welcomed by the public for their effectiveness and their considerably lower cost in comparison with the other currently available anti-malarial products. They have been sold officially in Cameroon since 2008.

All these policies on the part of the Chinese state with regard to the spread of TCM in Cameroon have had various outcomes, and have even generated different forms of TCM.

\section{The reception of TCM in Cameroon}

The reception of TCM in Cameroon has benefited above all from the inadequacy of the existing health care infrastructure in the country, which is unable to deal with all of the population's health problems. This paucity has opened the way for several kinds of practice, via the opening of private surgeries and the sale of TCM products. This phenomenon, which has its problematic side and provokes some debate, arose in the late 1990s and the early 2000 s.

\section{A state of medical infrastructure favourable to TCM}

The Cameroonian health system is tripartite, and each part has its own administrative structures, health training programmes, and means of deliberating on its approach to specific issues. The central structure includes the main services provided by the Ministry of Public Health, the general hospitals, the teaching hospitals and the central hospitals. Next, there is the intermediary level, which includes the regional public health boards, the regional hospitals, and their dependent units. On the periphery are the district health services, the area medical centres, and the health centres under their supervision. The health sector is also divided into three sub-sectors: public, private, and traditional medicine.

Overall, the Cameroon health system is made up of four general hospitals, four central hospitals, 11 regional hospitals, 164 district hospitals, 155 area medical centres, and 1,888 health centres in the public sector, out of which 1,600 are operational. To these should be added 93 private hospitals, 193 non-profit-making health centres, 289 clinics/polyclinics, and 384 care centres. In addition, there are 12 licensed analytical laboratories, the main one being the Pasteur Centre, five medicine manufacturers, 14 wholesalers, 331 medical workshops, a national centre for the supply of medicines and medical consumable goods, 10 regional pharmaceutical supply centres, three public university medical faculties and one private one, and 39 training establishments in health and medical care.

In 2010, Cameroon had a population of 19.4 million inhabitants. ${ }^{(34)}$ The ratio of inhabitants to doctors and nurses has deteriorated, growing from 10,084 inhabitants per doctor in 2005 to 14,418 in 2009, and from 2,249 inhabitants per nurse to 2,545. ${ }^{(35)}$ Cameroon's medical resources do not yet meet the standards set by the $\mathrm{WHO},{ }^{(36)}$ and this gives TCM fertile ground for expansion.

\section{The practice of TCM mainly through private clinics}

TCM is practised mainly in private clinics belonging to Chinese or to Cameroonians. These clinics have emerged in a general situation in which private health care, mostly specialising in traditional African medicine, is booming in Cameroonian cities. (37) These kinds of medicine appear under different names and have become a striking feature in the history of

30. Michel Bruneau, "Diasporas, transnational spaces and communities," in Rainer Bauböck and Thomas Faist (eds.), Diaspora and transnationalism: Concepts, theories and methods, op. cit., p. 49.

31. Emmanuel Ma Mung, "Chinese migrations and China's policy in Africa," art. cit., p. 92.

32. According to an interview with Doctor Langueu on 25 May 2011.

33. In the year 2010-2011, the total number of grants in all fields and at every level was 24 .

34. The National Statistical Institute of the Cameroon Republic, "2nd inquiry into the outcome of public expenditure and the levels of satisfaction in the education and health sectors of Cameroon" (PETS 2), Main Report, Health Section, December 2010, p. 12.

35. Ibid., p. 14.

36. By way of comparison, as of 2011 , France has 35 doctors and 89 nurses and midwives for every 10,000 inhabitants, while the proportions for Cameroon are 1.9 and 16, respectively (www.who.int/whosis/ whostat/2011/fr/index.html pp. 116, 118).

37. François Wassouni, "La présence chinoise au Cameroun et son influence sur les pratiques de santé," art. cit., p. 104. 
healthcare in Cameroon, Africa, and even in the West generally, to such an extent that Olivier Schmitz's opinion that in Europe "the coexistence of multiple medical practices has become commonplace, and no longer surprises anyone" (38) could apply equally to Cameroon.

Many of the private TCM permanent clinics in Cameroon are owned by Chinese doctors, while others only open on a seasonal basis. These doctors operate as private businessmen, just like those found in Tanzania. ${ }^{(39)}$ While some of these clinics are licensed by the Cameroon authorities, larger numbers of them have no legal status. Our enquiries have not been able to ascertain the exact number of these clinics, or even the number of Chinese doctors practicing in them.

We were able to meet Dr. Yen, ${ }^{(40)}$ a specialist in internal medicine trained in China. The tenor of our interview gives some idea of the nature of a TCM clinic run by Chinese doctors. The Saint-Esprit clinic was set up under the arrangements for bilateral co-operation between a private organisation and a partial commitment by the State of Cameroon. The latter authorised its formation and licensed its opening on 1 January 1999. Since that date, Chinese doctors have been coming from China to practice for two years before going home. This regular turnover, in Dr.Yen's view, provides the mobility necessary for effective medical work.

The clinic is equipped for gastroscopy, ultrasound scanning, x-ray examinations, electrocardiography, laboratory work, and physiotherapy. It includes a pharmacy containing mostly traditional Chinese remedies. The range of its services covers general medicine, surgery, obstetric gynaecology, paediatrics, nose and throat treatment, acupuncture, and massage.

This clinic only prescribes TCM drugs sold on the premises. It sometimes combines traditional local medicines with this treatment. The patient has to spend 2,000 FCFA (3.05 euros) to be registered prior to any consultation.

It is not linked by any partnership to other Chinese-run clinics. However, there is a partnership involving local traditional medicine. Because of that, its general overseer is a Cameroonian herbal doctor. In the event of a disruption in the supply of Chinese medicines, some patients are sent to the hospital in Ngousso, where they can obtain them quickly. In this clinic, the Chinese doctors are currently engaged in training their Cameroonian employees in TCM. The chemist, for example, already practices massage and acupuncture. ${ }^{(41)}$

With regard to relations with the local population, Dr. Yen tells us that he does not maintain professional relations with his compatriots, but takes part in the Cameroon-Chinese social club. As for adapting to his Cameroonian surroundings, he is trying to learn French and English, and is getting used to the local cuisine. The major difficulty he encounters is language problems. To overcome it, the Chinese doctors have compiled a Franco-Chinese dictionary. All the employees make an effort to learn Chinese. In addition to this, the difficult climate has a deleterious effect on the chemical composition of the plants. That is why the doctors continue to order ready-made medicines from China.

As Elisabeth Hsu has shown with regard to Tanzania, some Chinese doctors are very mobile. They come to Cameroon in a team, and set up seasonal clinics in a number of towns for a limited period. For example, they were in Bafoussam in 2008, Dschang in 2009, and in Bandjoun at the beginning of this year. Some of them reach agreements with public hospitals to use premises for consultations. Thus, the Yom district hospital in Bandjoun was used by a team at the beginning of this year. In Dschang, three medical teams visited for stints of six months each. To publicise their ac- tivities, some teams announce their arrival at Church gatherings, bringing their medicines with them and advertising the time and place of their consultations. The problem with this type of clinic is in patient follow-up, because it is by no means certain that a diagnosis can lead to complete treatment while the doctors are still in place.

Some Cameroonians are trained in TCM and have also opened their own clinics. It is difficult to know exactly how many there are. In 1999, there were already four known clinics in Yaoundé. Nowadays they appear to have spread throughout the capital. Yet there are only two TCM clinics in the telephone directory. Some of these practitioners have studied in China, and others have been trained locally by their Chinese or Cameroonian colleagues, but others are simply quacks who set up as doctors with no prior training.

In preparing this article I met one of the TCM pioneers in Cameroon, Mr. Elie Langueu, whose career demonstrates the key role he played in bringing TCM to Cameroon and making it widely known. He was trained in China, and has carried out many exercises to promote the practice of TCM in Cameroon. He holds a certificate in modern Chinese language from the Beijing Foreign Languages Institute, he is a member of the International Acupuncture Academy, and he has a Chinese State doctorate from the Beijing Institute of Chinese Medicine. He taught medical semiology at the Guinea Health School from 1969 to 1974. In that country he worked with a Chinese medical team to encourage the state to take an interest in medicinal plants.

He returned to Cameroon in 1974, where he was appointed assistant chief to the Chinese medical mission in Mbalmayo and Guider (19751981). Supported by a WHO grant, he returned to China in 1977. Upon his return to Cameroon, he was immediately appointed chief medical officer of the Mbalmayo hospital (1977-1982), where the Chinese were already practicing acupuncture. There he trained 20 nurses in various areas of acupuncture. He wrote a report for the government about this training, which introduced acupuncture into Cameroonian medical terminology. Following that, he contributed to setting up a Cameroonian syndicate of acupuncturists, which did not become active, owing to lack of funds. After his retirement in 1997, he opened a medical research clinic in the town of Dschang, where he still practices TCM in the form of acupuncture and by encouraging his patients to treat themselves by using Tianshi products in particular. ${ }^{(42)}$

Some of the Cameroonians practicing TCM have been trained in China, while others have trained locally over a period of about two years, under Chinese doctors or other compatriots who have already been trained. These Cameroonians practice TCM exclusively in their own clinics. The health products they prescribe come from a range of Chinese medicines that they buy on the open market. They use "soft" methods or "non-conventional medicine," following the same pattern as Dr. Langueu, who believes TCM to be "medicine making use of nature and applied by natural means, without any violation." "The range of TCM practices by these Cameroonians covers acupuncture, internal medicine, surgery under acupuncture anaesthetic,

38. Olivier Schmitz (ed.), Multiplicité des médecines et quête de soins dans les sociétés occidentales contemporaines, les médecines parallèles. Multiplicité des recours au soin en Occident, Paris, Karthala, 2006, p. 6.

39. Elisabeth Hsu, "Medicine as business: Chinese medicine in Tanzania," art. cit., pp. 8-16.

40. An interview in the Saint-Esprit Chinese clinic in Bafoussam on 20 July 2011.

41. Interview with Professor Ndediffo Albert, director of the Saint-Esprit clinic, on 20 July 2011.

42. Interview with Dr. Langueu on 25 May 2011. 
etc." (43) The Cameroonian population is increasingly resorting to acupuncture, which is carried out in private centres. They discovered it around 30 years ago, thanks partly to Sino-Cameroonian co-operation in the healthcare field, but especially due to the efforts of Dr. Langueu. It is used especially for certain types of complaints such as paralysis, rheumatism, diabetes, high blood pressure, nervous complaints, etc. A few years ago the Chinese hospital in Mbalmayo was the only place suitable for such care. Nowadays, identical procedures are available in both hospitals and private clinics. Each session costs from 10,000 to 15,000 FCFA (15 to 23 euros).

\section{The promotion and sale of traditional Chinese medicines by private Chinese companies}

Traditional Chinese medicines are not only dispensed through hospitals and private clinics but are also sold by private companies and individuals. Some private Chinese companies such as Tianshi, Tasli, Somai, and Meilun (44) undertake the promotion of TCMs. They prepare them and put them on the market, or supply them directly to patients. They also train other Cameroonians in China or locally.

For several years now, the main outlet for TCM products has been street sales. Other ideal venues for popularising knowledge of Chinese medicines include major thoroughfares, travel agencies linking major cities, and trains providing connections for travellers between the north and the south. Distribution is handled by Cameroonians recruited and trained by Chinese TCM companies, or by those who replenish their own stock on the open market. They are generally educated and present themselves as doctors in order to persuade their intended clients. They have become real marketing experts in that product line. According to Gaétan Teje, "The marketing strategy consists of getting the TCM products in your brief known, loved, bought, and widely discussed." (45) One Chinese man has become an expert in this kind of marketing. Being a resident of Maroua, a town in the far north of Cameroon, he goes back and forth through its residential areas, selling Chinese medicines. His activities resemble those of some of his compatriots in N'Djamena, a town in Chad. ${ }^{(46)}$

\section{A medical practice with a problematic side}

The practice of TCM in Cameroon entails certain problems that are far from being solved. The first is the language barrier, which is a problem encountered by Chinese everywhere in Africa. ${ }^{(47)}$ Being proficient in Chinese only, most of these doctors find it difficult to communicate in French or English. In the Yaoundé hospital, we were told, "Some doctors get by in English without interpreters, while others need them." (48) That is why Professor Doh, director of the hospital, suggested that Chinese should take courses in French or English before coming to Cameroon. Another problem is the admission of quacks into the profession, facilitated by the proliferation of private clinics.

As Dr. Langueu points out, the large-scale enrolment of quacks is very dangerous for public health:

\section{They give a bad image to TCM in Cameroon, discrediting it through the dangers they represent. They prevent sick people from getting a proper consultation. ${ }^{(49)}$}

This grey area is further obscured by the proliferation of private clinics, which is drawing the disapproval of the national organisation of doctors and health authorities. In 1999, the Ministry of Public Health established a commission charged with identifying and closing unlicensed clinics. In the city of Yaoundé, several Chinese-owned clinics were closed, while those owned by Cameroonians are often kept open but are forbidden to practice acupuncture, in order to avoid the spread of HIV/AIDS. Three other health organisations were closed down in Douala in 2009, including Dr. Liu's Chinese medicine centre and the Chinese medical clinic Family Life Welfare, which were accused of practicing medicine illegally. According to the provincial health representative for the coastal area:

Chinese medicine in Cameroon is subject to governmental agreements, and through the Ministry of Public Health the government has signed an agreement with the Chinese Ministry of Health. In accordance with this, the regulations only allow the Chinese hospitals in Mbalmayo and Figuil, the hospital for obstetric gynaecology in Ngousso, and soon the one in Douala. The other organisations are illegal, insofar as the majority do not observe the current regulations and do not possess the required documents.

Since 1998, several professional organisations have been set up, including three associations of Cameroonian specialists within the Cameroonian Association for the Promotion of TCM. They are attempting to regulate admission to the profession by enabling a more precise definition of the distinction between "real" doctors and quacks. Unfortunately, I have been unable to meet any members of these associations, but I interviewed an official from another association, the Organisation of the Traditional Medicine Sector in the West (OSEMETO). They practice Chinese medicine and currently have 700 members. They aim at popularising TCM through organising seminars in collaboration with associations from other parts of the country. ${ }^{(50)}$ The dynamism of these organisations bears witness to the fact that, despite the instances of dysfunctional practices surrounding it, TCM is nonetheless an activity that benefits both Cameroon and China.

\section{A "win-win" activity for Cameroon and China}

TCM is a "win-win" activity for Cameroon and the PRC. While bringing benefits to Cameroon, I believe it also constitutes a power strategy for China. This can be shown by highlighting the way Chinese doctors in fact take up a midway position between Cameroon and China, functioning as a third term within the triangular social structure in which they interact with the other two.

\section{TCM as a Chinese power strategy}

Contemporary analyses of migratory patterns, which have undergone considerable development in recent times, emphasise the need to see the mi43. Ibid.

44. Interview with Simon Djouatsa, dispenser and practitioner with the Meilun company in Dschang, on 30 May 2011.

45. Gaétan Teje, "'Le marketing du bus'. Les stratégies des vendeurs ambulants pour conquérir les voyageurs interurbains," Les dossiers experts de la masse, no. 1, August 2007, p. 4

46. François Wassouni, "La présence chinoise au Cameroun et son influence sur les pratiques de santé," art. cit., p. 106.

47. Giles Mohan, "Chinese migrants in Africa as new agents of development? An analytical framework," art. cit., p. 19

48. Interview with a nurse at the Yaoundé hospital on 11 July 2011.

49. Interview with Dr. Langueu on 25 May 2011.

50. Interview with Professor Ndediffo Albert, director of the Saint-Esprit clinic, on 20 July 2011. 
grant not only within the social context of the host country, but also in terms of the links he retains with his homeland. This observation by Alain Tarrius, supported by Antoine Kernen, ${ }^{(51)}$ suggests that the medical activities of Chinese migrants to Cameroon are a consequence both of Chinese government policy and of individuals taking advantage of the opportunities provided. This dual motive behind their activity gives rise to a measure of interdependence between themselves and their homeland, (52) setting up a kind of axis for China's governmental strategy in Africa. Chinese pragmatism and market logic have jointly facilitated the global deployment of China's power strategies along different axes: economic, diplomatic, military, scientific, technological, socio-cultural, medical, and media-based. ${ }^{\left({ }^{(33)}\right.}$ Chinese medical activity in Cameroon is one aspect of this projection of China's power in Africa. Thus TCM is used to mobilise support for a political, economic, and cultural project. Moreover, at the second "International Conference on Technologies to Modernise Traditional Medicine" held in Chengdu in 2005, China officially announced its decision to make traditional medicine a strategic sector.

The Chinese government's medical achievements in Cameroon have a strategic political dimension. ${ }^{(54)}$ The Chinese medical personnel working there on a temporary basis since 1975 constitute a body of agents whose observations add to China's economic intelligence in the country. In addition, it is no longer a secret that Africa has become a field of geopolitical competition between Washington and Brussels on the one hand, and Beijing on the other. The continuing presence of Chinese doctors in Cameroon in particular, and in Africa generally, is part of the strategy of laying the groundwork for the conquest of Africa from below, as Antoine Kernen has written. This goes to show that there is not one single "Chinese strategy" in Africa, but rather a variety of networks to be taken into account.

The Chinese doctors who have established themselves in Cameroon in private clinics and in Chinese companies selling TCM products on a commercial basis are extending the power of their country, and for that very reason they are courted by the Chinese authorities. ${ }^{(55)}$ They are described as a sort of "unique cultural, material, and political resource" (56) simply because they are means for channelling symbolic and strategic resources through the multiform exchange relations they establish between themselves and their homeland.

Over and above this political dimension, however, Chinese doctors have come, like their fellow professionals in Tanzania, for economic reasons - in other words, "to do business." (57) In pursuit of this goal, some of them are even ready to change professions, like Dr. Yen in the Bafoussam clinic. Their main priority is making money. In this respect they are entrepreneurs who have come to Africa, like most of their compatriots, to find new ways of changing their social status. ${ }^{(58)}$

Medical personnel in Cameroon are also a symbolic resource for China. They play an important role in consolidating cultural networks through the multiplication of health centres promoting TCM. They are therefore "strategically important because of their linguistic and cultural roles in constructing the ideology of the State and national identity, thereby ensuring the process of cultural reproduction." (59) In addition, through their presence and the ready availability of Chinese medicines, the presence of China itself is made more visible in Cameroon. In Cameroon, as in other African countries, this visible presence bolsters China's status as a world power. As in Europe and the United States, the strong presence of Chinese communities in French-speaking Africa and in East Africa provides support for China. ${ }^{(60)}$ They give visibility to Chinese power, which the authorities on the mainland wish to project abroad. ${ }^{(61)}$
At the same time, these doctors are part of a globalisation process in which China is deeply involved because, as Évelyne Micollier puts it: "Disseminated by expatriate Chinese doctors in search of fame and fortune, studied worldwide by practitioners of alternative and non-conventional medicine, and valued by an international clientele, Chinese medicine is becoming a global phenomenon and an object of large-scale marketing." (62) They are effectively agents of globalisation, playing an important role in consolidating the cultural and economic networks that have enabled China to become integrated into the global economy. This mutual economic support, facilitated by modern means of communication and transport, as well as by territorial interdependence at the level of the world system, also depends upon a far-reaching shift in the way that overseas Chinese are viewed by their homeland government. Through their ability to develop new areas of competence, which they bring with them and which bind them together, and through their capacity to maintain - or even to strengthen - the relationships already established in the diaspora, these Chinese doctors are in effect "agents of a 'discrete' form of globalisation (based on survival strategies)." (63) Thus, "Although it is necessary to examine the developing role played by States in the globalisation process, this should not mean overlooking the role played by human individuals in the same process." ${ }^{(64)}$ As F. E. Pieke argues:

\section{Chinese emigration is no longer simply a movement towards the cen- tre of a world dominated by the West, but is just as much an extension of a world with China at its centre. This mobility is just one of the as- pects of the globalisation of Chinese society, culture, and economy. ${ }^{(65)}$}

The Chinese companies purveying TCM products, along with other sales outlets, are also bringing profits to China. In 2001, the export of medicine brought in $\$ 9.76$ million, and China is already exporting medicine to 37 African countries. ${ }^{(66)}$

51. Antoine Kernen, "Les stratégies chinoises en Afrique: du pétrole aux bassines en plastique," Politique africaine, no. 105, March 2007, p. 176.

52. Dario Battistella, Théories des relatiions internationales, op. cit., p. 186

53. Marie Bal and Laura Valentin, La stratégie de la puissance de la Chine en Afrique, op. cit., p. 18.

54. Adama Gaye, "La nouvelle donne chinoise en Afrique," www.gabrielperi.fr/La-nouvelle-donne-chinoiseen?lang=fr (consulted on 31 October 2011).

55. For further details see, for example, Hélène Franchineau, "De la régionalisation au régionalisme: la diaspora chinoise et l'intégration de la Chine en Asie du Sud-Est," www.cean.sciencespobordeaux.fr/ pageperso/franschineau.pdf (consulted on 31 October 2011).

56. Myra A. Waterbury, "Bridging the divide: Towards a comparative framework for understanding kin state and migrant-sending state diaspora politics," in Rainer Bauböck and Thomas Faist (eds.), Diaspora and transnationalism: Concepts, theories and methods, op. cit., p. 133

57. Elisabeth Hsu, "Medicine as business: Chinese medicine in Tanzania," art. cit., p. 8.

58. Sandrine Perrot and Dominique Malaquais, "Afrique, la globalisation par les Suds," Politique africaine, no. 113, March 2009, p. 6

59. Myra A. Waterbury, "Bridging the divide:Towards a comparative framework for understanding kin state and migrant-sending diaspora politics," art. cit., p. 139.

60. François Lafargue, "La Chine, une puissance africaine," op. cit.

61. Thierry Sanjuan, "Le monde chinois en redéfinition. D'un empire autocentré à une identité culturelle multipolarisée," Géoéconomie, no. 18, Summer 2001, p. 2: www.geochina.fr/telechargements/ monde_chinois_article_geochina.pdf

62. Evelyne Micollier, "Les transformations de la médecine chinoise en Chine: recherche et développement, circulation des savoirs et des pratiques," art. cit., p. 3.

63. Views quoted by Laurence Roulleau-Berger, "Nouvelles migrations chinoises et marchés du travail," art. cit., p. 15. Alejandro Portes, "La mondialisation par le bas," Actes de la recherche en sciences sociales, vol. 29, September 1999, pp. 15-25.

64. Wang Chunguang, "Migrations chinoises en Europe: un regard depuis la Chine," in Laurence RoulleauBerger (ed.), Nouvelles migrations chinoises et travail en Europe, op. cit., p. 229.

65. F. E. Pieke, "Les migrations chinoises contemporaines: nouveaux régimes et nouvelles activités en Europe," in Laurence Roulleau-Berger (ed.), Nouvelles migrations chinoises et travail en Europe, op. cit., p. 20.

66. François Wassouni, "La présence chinoise au Cameroun et son influence sur les pratiques de la santé," art. cit., p. 107. 
Finally, Chinese efforts in the public and private sector complement each other in their aim of gaining a leading role in Africa, and the Chinese doctors in Cameroon play their part in these efforts.

\section{An activity that is equally beneficial to Cameroon}

Chinese doctors are not only linked to China, but also interact with Cameroonian society where they practice. In this way, TCM exercises a real influence on Cameroon. It is considered all the more valuable and beneficial to the country because it is cheap and requires little in the way of infrastructure. It was for the same reasons that, from the founding of Communist China by Mao Zedong, "barefoot doctors" were trained on the spot to provide care to both the army and the people. This explains why the President of Cameroon, when he visited China last July and thanked $\mathrm{Hu}$ Jintao for China's contributions to Cameroon, including the work of Chinese doctors, took the opportunity to assert that "China is among the most steadfast and faithful partners of our country." (67)

Indeed, after a presence lasting over 30 years, Chinese doctors continue to sell their expertise for the good of many Cameroonians. ${ }^{(68)}$ They have made an enormous contribution to healthcare provision in Cameroon through the building of hospitals and private care centres, the placing of specialists, the training of Cameroonians, and above all the donation of medical equipment, which has raised the technical level of the care provided. The latter has proved to be a real master stroke, given the situation in which the Cameroonian hospitals face huge problems in finding qualified staff and overcoming equipment shortages. The Chinese medical missions have quickly become celebrated and useful on account of their effectiveness and their low cost, which puts them within the reach of all in times of economic crisis. The following statement by a TCM practitioner is very significant:

Our natural products are less expensive than Western medicines or other natural products, like those of the Americans. They are also more effective. ${ }^{(69)}$

In addition, the medicines are more readily available, as are Chinese manufactured goods. All these contributions from the Chinese have considerably improved the system of medical provision and reshaped the healthcare map in Cameroon.

There is also the matter of the transfer of Chinese expertise to Cameroonian medical personnel. Chinese doctors give close attention to all patients without discrimination. This is an unusual attitude in Cameroonian healthcare, where corruption, lack of attention to patients, and other behaviour contrary to good practice are endemic. ${ }^{(70)}$ According to Professor Doh, the main advantage of the co-operation is its practical applicability. Other strong points are the discipline, assiduousness, willing availability, and punctuality of the Chinese teams, all of which are widely appreciated by Cameroonian patients, as well as by Tanzanians, as Elisabeth Hsu has noted. ${ }^{(71)}$

Chinese medicine has also given hope to patients who were not satisfied with modern hospitals. The recruitment of Cameroonians into the distribution of medicine or private clinics, and the establishment of their own clinics by some of them, has contributed to overcoming unemployment.

Xue Jinwei, the Chinese ambassador to Cameroon, argues that his country's strategies do not mean that Cameroon loses out:
We are trying to respond to the real needs of the Cameroonian people. If there is one major criterion in considering the feasibility of our projects, it is to take account of the pressing needs of the Cameroonian people, and the need to strengthen the country's capacities for self-development. That is why, on the Chinese side, we give priority to sectors such as public health, the availability of drinking water, education, agriculture, telecommunications, infrastructural projects, etc. ${ }^{(72)}$

The Ministry of Public Health has also expressed satisfaction with this co-operation: "China's intervention in our country is very effective, and is outstanding for its remarkable concrete achievements."

Taken as a whole, then, the activities of Chinese doctors, which are increasingly welcomed by the local population, are making a real contribution to Cameroon's medical and healthcare services. It is nevertheless the case that TCM represents one of the links in China's power strategy in Cameroon and the rest of Africa, as it helps to ensure the status of China as a major power by adding to its global projection of soft power. By providing a cheap and culturally distinctive solution to recurrent deficiencies in the nation's medical system, TCM also intensifies the competition with other major powers. We know how China's sudden arrival in Africa has caused real anxiety among the continent's older partners, (73) but it should be added that China is also in competition with other newly arrived powers in Africa, such as Japan. ${ }^{(74)}$ And Cameroon is obviously an important area within the strategic zones where these confrontations are being played out. The willingness of the Chinese government to improve the research and development of TCM in Cameroon has to be considered in this politically tense context of confrontation and influence, where strategic counter-attacks from other cultural competitors, including France, are already underway. ${ }^{(75)}$ The future of the heritage of TCM in Africa is therefore linked to currently pressing issues in international relations, and is inseparable from the phenomenon of globalisation. It allows the Middle Kingdom to play an active role by imposing itself in the vital area of healthcare and thereby becoming a major player in the globalising process, which is both an outcome of migration and the scene of its future challenges. ${ }^{(76)}$

\section{Translated by Jonathan Hall}

67. Cameroon Tribune, 25 July 2011, p. 3.

68. Most of the patients interviewed at the Chinese clinic in Bafoussam and the hospital in Yaoundé expressed overall satisfaction with the contributions made by these organisations.

69. Interview with Djouatsa Simon, dispenser and practitioner with the Meilun company in Dschang, 30 May 2011.

70. François Wassouni, "La présence chinoise au Cameroun et son influence sur les pratiques de la santé," art. cit., p. 110.

71. Elisabeth Hsu, "Medicine as business: Chinese medicine in Tanzania," art. cit., p. 10.

72. Interview with Xue Jinwei, The Chinese Ambassador to Cameroon, by Simon Pierre Etoundi, published in Cameroon Tribune on 16 November 2011.

73. Chris Alden, Daniel Large and Ricardo Soares de Oliveira, "China Returns to Africa: Anatomy of an Expansive Engagement," Working paper 51/2008, Madrid, Real Instituto Elcano de Estudios Internacionales y Estratégicos, 11/12/2008, www.realinstitutoelcano.org (consulted on 31 October 2011).

74. According to Takeshi Iwaya, the Japanese vice-Foreign Minister, "The next challenge is Africa." Jeune Afrique, no. 2427, 15-21 July 2007, p. 32.

75. Jérôme Balluet et al., "Stratégie française d'intelligence économique face au BTP chinois en Afrique," 30 June 2005, www.ege.fr/download/etude_BTP_Afrique_presentation.pdf (consulted on 14 March 2011).

76. Pierre de Senarclens, La mondialisation. Théories, enjeux et débats, Paris, Armand Colin, 2005, p. 146. 